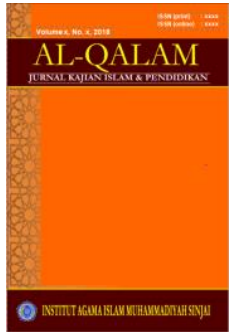

AL-QALAM

Jurnall Kajian Islam \& Pendidikan

Volume 9, No. 1, 2017

ISSN (print) : 1858-4152

ISSN (online) : :xxx-xxxx

Homepage : http://journal.iaimsinjai.ac.id/index.php/al-qalam

\title{
SIGNIFIKANSI SOSIO-EMOSIONAL KEPALA SEKOLAH TERHADAP EFEKTIVITAS KINERJA
}

\author{
Oleh: Madalle Agil
}

$* * *$

\begin{abstract}
Abstrak
Penelitian ini bertujuan untuk menganalisis pengaruh kemampuan sosio-emosional kepala sekolah terhadap efektivitas kinerjanya di Kabupaten Sinjai. Metode penelitian yang digunakan adalah survey explanatory yang bertujuan menguji hipotesis dengan menggunakan metode sampling. Penarikan sampel dilakukan melalui teknik sampling acak bertingkat. Pengumpulan data dilakukan dengan teknik dokumentasi dan teknik angket. Penelitian ini menggunakan metode kombinasi yaitu metode kuantitatif yang dominan didukung dengan metode kualitatif. Data kuantitatif dianalisis dengan analisis jalur yang diolah dengan menggunakan software SPSS, sedangkan data kualitatif dikumpulkan melalui dokumen dan angket, lalu direduksi, dan disajikan.Hasil Penelitian menunjukkan bahwa kemampuan sosioemosional memfokuskan pada tiga dimensi yaitu (1) Keterampilan emosi yang meliputi: kesadaran emosi diri, kesadaran emosi terhadap orang lain, peristiwa dalam hidup.; (2) Kecakapan emosi yang meliputi: Intensionalitas, kreatifitas, ketangguhan, hubungan antarpribadi, dan kepuasan konstruktif; dan (3) Nilai-nilai emosi dan keyakinan, yang meliputi: belas kasihan, sudut pandang, Intuisi, radius kepercayaan, daya pribadi, serta integritas. Baik sendiri-sendiri maupun simultan berpengaruh signifikan terhadap efektivitas kinerja pada kategori sangat tinggi.
\end{abstract}

KATA KUNCI : Kemampuan sosio-emosional, Efektivitas kinerja

\section{PENDAHULUAN}

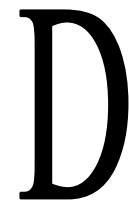

Desentralisasi pendidikan artinya pelimpahan wewenang dari pemerintah pusat kepada pemerintah daerah untuk mengatur dalam bidang

${ }^{1}$ Pengawas Tingkat SMA/SMK di Sulawesi Selatan dan Dosen Luar Biasa Pada Institut Agama Islam Muhammadiyah Sinjai 


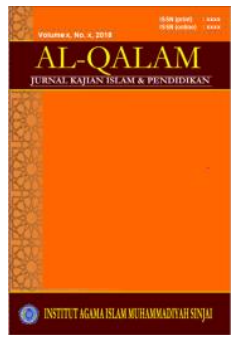

pendidikan. Dalam kerangka desentralisasi pendidikan tersebut, kepala sekolah mempunyai wewenang yang lebih luas dalam menentukan pencapaian tujuan yang mengarah pada keberhasilan dan efektivitas pendidikan serta meningkatkan mutu pendidikan.

Peningkatan efektifitas di sekolah sangat ditentukan oleh kinerja kepala sekolah. Kepala sekolah yang berkinerja baik diperlihatkan dalam kemampuan manajemen kepala sekolah yang mampu: (a) menjabarkan sumber daya yang ada untuk menyediakan dukungan yang memadai bagi guru, bahan pengajaran dan pemeliharaan fasilitas yang baik; (b) memberikan waktu yang cukup untuk pengelolaan dan koordinasi proses instruksional; (c) berkomunikasi secara teratur dengan staf, orang tua, siswa, masyarakat terkait dan pemerintah dalam hal ini dengan dinas pendidikan. Dengan kata lain, bahwa efektivitas sekolah ditentukan oleh kemampuan manajerial kepala sekolah. Selain itu, efektifitas sekolah ditentukan pula oleh kinerja kepala sekolah yang kompeten secara umum harus memiliki pengetahuan, keterampilan, sikap, performance, kecerdasan emosi dan etika kerja sesuai dengan tugas dan tanggung jawab sebagai kepala sekolah. ${ }^{2}$

Terdapat beberapa faktor yang diduga dapat mempengaruhi derajat kemampuan manajerial kepala sekolah dalam melaksanakan manajemen sekolah. salah satunya adalah pengetahuan yang dimiliki oleh kepala sekolah tentang manajemen sekolah itu sendiri. Manajemen sekolah di era otonomi merupakan konsep yang menawarkan kerjasama yang erat antara sekolah, masyarakat, dan pemerintah dengan tanggung jawab masing-masing. Manajemen sekolah berkembang didasarkan pada suatu keinginan untuk pemberian kemandirian (otonomi) kepada sekolah untuk ikut terlibat secara aktif, dinamis dan bertanggung jawab dalam upaya peningkatan kualitas pendidikan melatui sumber daya sekolahyang ada.

\footnotetext{
${ }^{2}$ Depdiknas. Standar Kompetensi Kepala Sekolah. (Penerbit Direktorat Penjaminan Mutu Pendidikan Menengah, Departemen Pendidikan Nasional. 2007), h. 102
} 


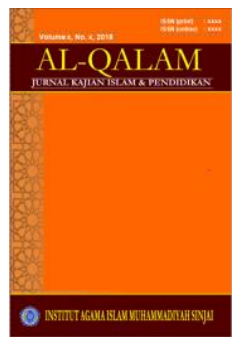

AL-QALAM

Jurnal Kajian Islam \& Pendidikan

Volume 9, No. 1, 2017

ISSN (print) : 1858-4152

ISSN (online) : xxxx-xxxx

Homepage : http://journal.iaimsinjai.ac.id/index.php/al-qalam

Faktor yang lain diasumsikan mempengaruhi kemampuan manajerial adalah kecerdasan emosional yang dimiliki oleh kepala sekolah. Salah satu pengertian kecerdasan emosional adalah : "Kemampuan atau keterampilan dalam mengendalikan diri, memiliki semangat dan ketekunan tinggi mampu memotivasi dirinya sendiri dalam mengerjakan sesuatu dan mampu berinteraksi dengan baik dengan orang lain" (Bahauddin, 1999: 179)

Tingkat kecerdasan emosional yang dimiliki seorang kepala sekolah dapat memandunya untuk bereaksi terhadap berbagai hal yang berkait dengan kegiatan manajerial yang dilakukannya.

"Kecerdasan emosi tidaklah ditentukan sejak lahir (bukan bawaan/bakat), ia dapat dipupuk dan diperkuat dalam diri kita”. Goleman (1999 ) menyatakan "IQ praktis tidak menawarkan persiapan untuk mengahadapi gejolak atau kesempatan yang ditimbulkan oleh kesulitan-kesulitan hidup". Tetapi kenyataannya selama ini sekolah dan budaya bangsa Indonesia lebih menitik beratkan pada kecerdasan intelektual, dan mengabaikan kecerdasan lain termasuk kecerdasan emosional.

Cooper dan Aiman Syawaf (2001. xxxviii) mengatakan "Ada orang kaya dengan pikiran sehat dan kreatifitas tetapi dikenal tidak berprestasi baik dalam ujiuji akademik" lni mengingatkan bahwa kecerdasan intelektual di sekolah bukan segala-galanya.

Namun banyak diantara kita tahu tentang penemuan bahwa IQ mungkin berhubungan dengan hanya 20 persen dari keberhasilan di dunia nyata. Dengan kata lain, 80 persen keberhasilan ditentukan oleh bentuk-bentuk kecerdasan lain, termasuk Kecerdasan Emosi (Emotional Intelligence). Dengan adanya pendapat Kooper dan Goleman di atas, dapat menunjukkan dalam penelitiannya bahwa kesuksesan seseorang dalam dunia kerja 80 persen ditentukan oleh kecerdasan lain termasuk keeerdasan emosional dan 20 persen kecerdasan intelektual. Ini menunjukkan perlunya memperhatikan kecerdasan lain, termasuk kecerdasan emosional untuk dikembangkan. 


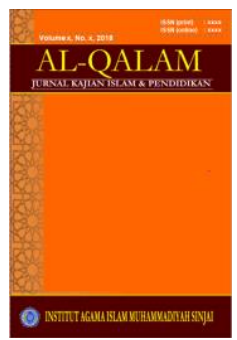

Volume 9, No. 1, 2017

ISSN (print) : 1858-4152

ISSN (online) : xxxx-xxxx

Homepage : http://journal.iaimsinjai.ac.id/index.php/al-qalam

Tingkat kemampuan manajerial Kepala Sekolah sangat mempengaruhi keberhasilan sekolah dalam mencapai visi dan misinya. Kenyataan itu, berlaku juga pada sekolah-sekolah di Kabupaten Sinjai. Setiap Kepala Sekolah memiliki gaya kepemimpinan yang berbeda-beda. Salah satu faktor yang berpengaruh adalah tingkat kecerdasan emosionalnya, dalam memanaj sekolah untuk mencapai visi dan misi yang telah ditetapkan. Penelitian ini ditujukan untuk memperoleh informasi tentang bagaimana signifikansi kemampuan sosio-emosional Kepala Sekolah dengan efektifitas kinerjanya?

\section{METODE PENELITIAN}

Metode penelitian yang digunakan adalah survey explanatory yang bertujuan menguji hipotesis dengan menggunakan metode sampling. Penarikan sampel dilakukan melalui teknik sampling acak bertingkat. Pengumpulan data dilakukan dengan teknik dokumentasi dan teknik angket. Penelitian ini menggunakan metode kombinasi yaitu metode kuantitatif yang dominan didukung dengan metode kualitatif. Data kuantitatif dianalisis dengan analisis jalur yang diolah dengan menggunakan software SPSS, sedangkan data kualitatif dikumpulkan melalui dokumen dan angket, lalu direduksi, dan disajikan. Variabel bebas yaitu Kemampuan sosio-emosional (kecerdasan Emosional), dan variabel terikat yaitu efektifitas kinerja di Kabupaten Sinjai

Populasi adalah totalitas semua nilai yang mungkin, baik hasil menghitung ataupun pengukuran kuantitatif maupun kualitatif dari karakteristik tertentu mengenai sekumpulan objek yang lengkap dan jelas yang ingin dipelajari sifatsifatnya. Sedangkan sampel adalah bagian dari populasi. Adapun anggota populasi dan sampel yang diteliti, dapat digambarkan dalam tabel 3 berikut :

Table 1. population and sample

\begin{tabular}{|c|c|c|c|c|}
\hline No & Nama Sekolah & $\begin{array}{l}\text { Kepala } \\
\text { Sekolah } \\
\text { (Populasi) }\end{array}$ & $\begin{array}{l}\text { Jumlah } \\
\text { Sampel }\end{array}$ & Keterangan \\
\hline 1 & SD & 242 & 56 & \multirow{2}{*}{$\begin{array}{l}\text { Stratified } \\
\text { Random }\end{array}$} \\
\hline 2 & SMP/MTs & 45 & 11 & \\
\hline
\end{tabular}




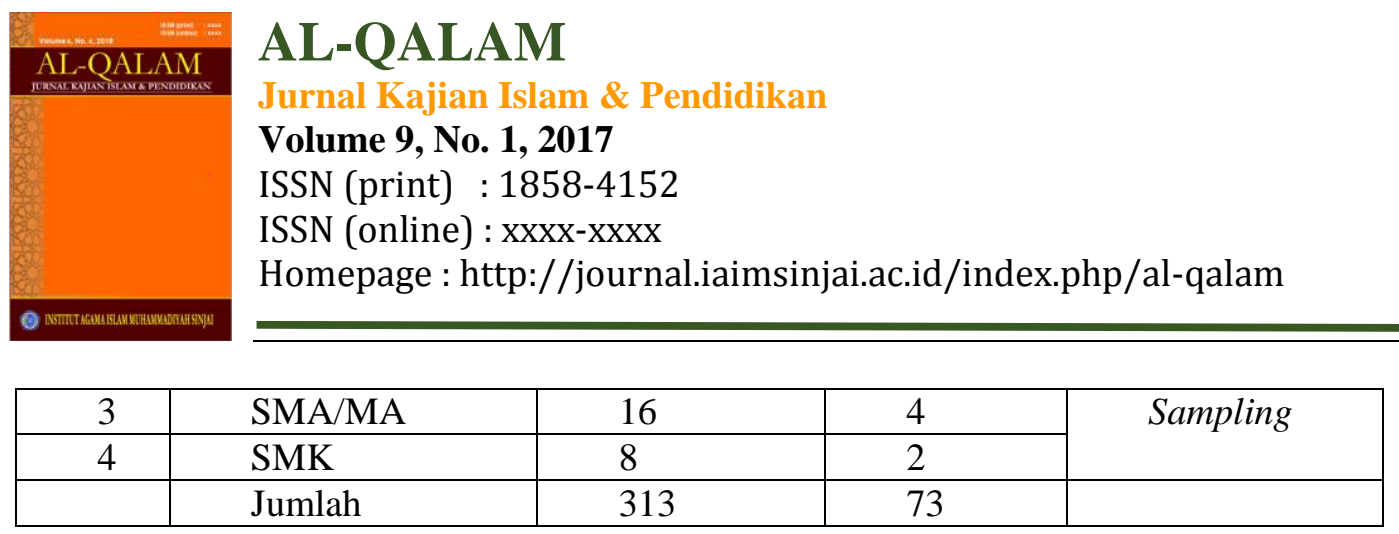

Sumber: Dinas Pendidikan diolah 2014

Teknik pengumpulan data dalam penelitian ini adalah (1) Teknik Dokumentasi dimaksudkan sebagai cara mengumpulkan data dengan mempelajari dan mencatat bagian-bagian yang dianggap penting dari berbagai risalah resmi yang terdapat baik di lokasi penelitian maupun di instansi lain yang ada hubungannya dengan fokus penelitian. (2) Teknik Angket yaitu menggunakan kuesioner yang disebarkan kepada responden.

Analisis data yang digunakan adalah path Analysis. Analisis ini untuk mengetahui kontribusi faktor-faktor strategis kemampuan sosio-emosional terhadap efektifitas kinerja kepala sekolah. Perhitungan teknik analisis menggunakan regresi linear dan corelation dengan jasa komputer program SPSS for Windows.

\section{HASIL DAN DISKUSI}

Untuk menjawab pertanyaan penelitian yang diajukan penulis, maka penulis berdasar pada hipotesis yang diajukan, karena penelitian ini bersifat kuantitatif yang didukung dengan kualitatif.

\subsection{Pengujian Asumsi Klasik}

\subsubsection{Uji Asumsi Normalitas}

Pengujian normalitas data penelitian adalah untuk menguji apakah dalam model statistik variabel-variabel penelitian berdistribusi normal atau tidak normal. grafik histogram memberikan pola distribusi yang mendekati normal yaitu berbentuk lonceng sehingga data dari variabel kemampuan sosio-emosional, dan efektifitas kinerja organisasi memiliki distribusi normal dan dapat digunakan dalam pengolahan data selanjutnya. 


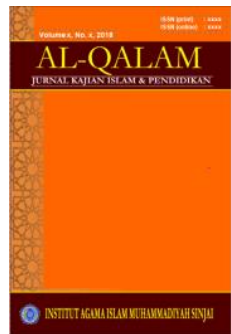

AL-QALAM

Jurnal Kajian Islam \& Pendidikan

Volume 9, No. 1, 2017

ISSN (print) : 1858-4152

ISSN (online) : :xxx-xxxx

Homepage : http://journal.iaimsinjai.ac.id/index.php/al-qalam

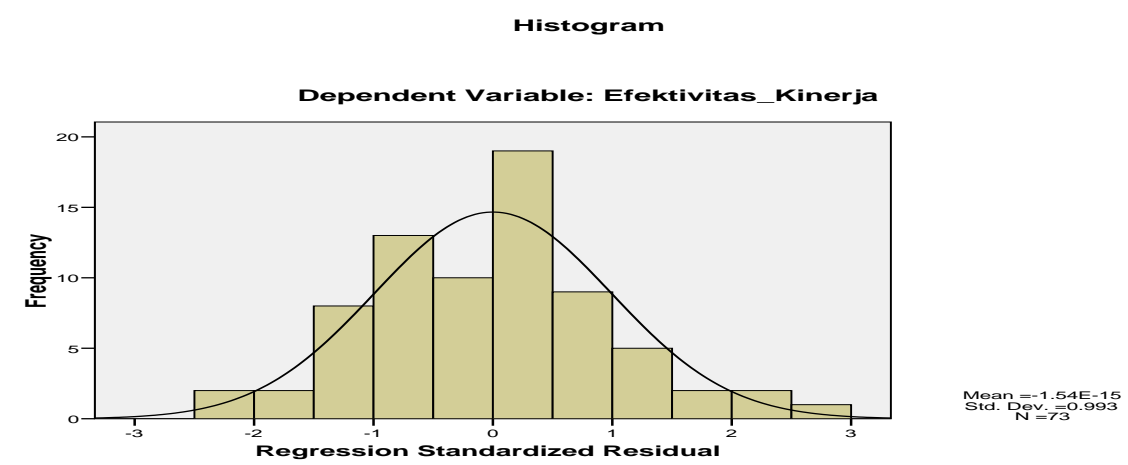

Gambar 1. Grafik Hitogram Normalitas

Metode gambar normal Probabilitas Plots digunakan untuk menyimpulkan apakah model path analisis memenuhi asumsi normal, dengan penyebaran data disekitar garis diagonal dan mengikuti arah garis diagonal maka data tersebut mememenuhi asumsi normal dalam model path analisis

Gambar 2. Model Normalitas Probability plots

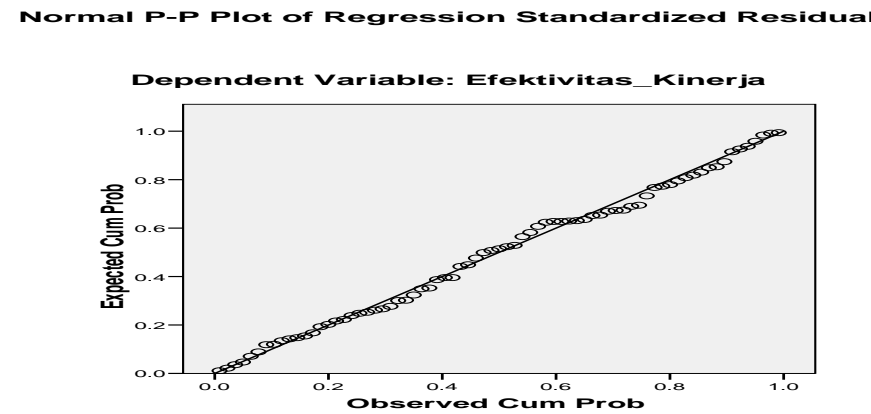

\subsubsection{Uji asumsi Autokorelasi}

Autokorelasi sebagai suatu korelasi antara nilai variabel dengan nilai variabel yang sama pada variabel satu atau lebih dari sebelumnya. Menurut Cornelius Tihendradi (2005: 212), kisaran nilai uji autokorelasi yang dilakukan 


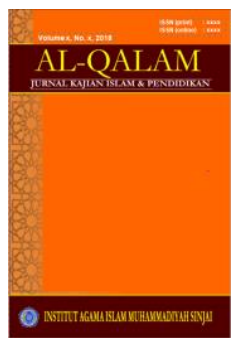

AL-QALAM

Jurnal Kajian Islam \& Pendidilkan

Volume 9, No. 1, 2017

ISSN (print) : 1858-4152

ISSN (online) : :xxx-xxxx

Homepage : http://journal.iaimsinjai.ac.id/index.php/al-qalam

dalam pengujian Durbin Watson (DW) sebagai berikut: $1.229<\mathrm{DW}>4-1.229$

$=2.771$ terjadi autokorelasi. Berdasarkan hasil pengolahan diperoleh nilai statistik

Durbin-Watson (DW) diperoleh nilai 1,544, nilai tersebut berada pada kisaran

$1.229<\mathrm{DW}>4-1.229=2.771$

\subsection{Analisis Korelasi dan Analisis Regresi}

Analisis korelasi bertujuan untuk mengukur kekuatan asosiasi (hubungan) linier antara dua variabel serta menyatakan derajat keeratan hubungan antar variabel terkait. Pada pengolahan data pada SPSS digunakan model analisis korelasi bivariate digunakan untuk mencari derajat keeratan hubungan dan arah hubungan, semakin tinggi nilai korelasinya semakin tinggi pula keeratan hubungan kedua variabel.

\subsubsection{Korelasi variabel secara parsial.}

Berdasarkan analisis secara parsial (individual) diketahui, masing-masing variabel memiliki keterkaitan satu dengan yang lainnya. Keterkaitan tersebut tidak hanya diantara variabel indenpenden dengan variabel dependen, akan tetapi nilai korelasi diantara variabel independen itu sendiri.

Tabel 2. Koefisien korelasi kemampuan sosio-emosional kepala sekolah dengan

Efektivitas kinerja

\section{Coefficients(a)}

a Dependent Variable: Efektivitas_Kinerja

1.2.2. Korelasi variabel kemampuan sosio-emosional kepala sekolah dengan Efektivitas kinerja 


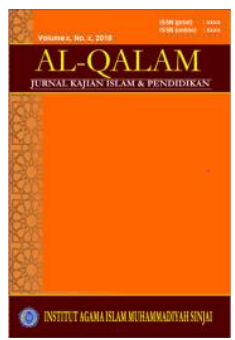

AL-QALAM

Jurnal Kajian Islam \& Pendidilkan

Volume 9, No. 1, 2017

ISSN (print) : 1858-4152

ISSN (online) : :xxx-xxxx

Homepage : http://journal.iaimsinjai.ac.id/index.php/al-qalam

Berdasarkan kepada hasil nilai koefisien korelasi secara simultan diketahui nilai korelasi kemampuan perencanaan, pengorganisasian, pemimpinan, kecerdasan emosional, pengawasan kepala sekolah dengan Efektivitas kinerja organisasi sebesar 0,967 . Nilai tersebut berada pada kisaran $0,81-10,00$, yang tingkat derajat kekuatan hubungan pada klasifikasisasi sangat kuat.

Tabel 3. Analisis Korelasi Simultan Model Summary(b)

\begin{tabular}{|c|c|c|c|c|c|c|c|c|c|c|}
\hline \multirow[t]{2}{*}{$\begin{array}{l}\text { Mode } \\
\text { I }\end{array}$} & $\mathrm{R}$ & $\begin{array}{c}\mathrm{R} \\
\text { Square }\end{array}$ & $\begin{array}{l}\text { Adjusted R } \\
\text { Square }\end{array}$ & $\begin{array}{c}\text { Std. } \\
\text { Error of } \\
\text { the } \\
\text { Estimat } \\
e \\
\end{array}$ & \multicolumn{5}{|c|}{ Change Statistics } & \multirow{2}{*}{$\begin{array}{c}\begin{array}{c}\text { Durbin- } \\
\text { Watson }\end{array} \\
\\
\text { Sig. F } \\
\text { Change }\end{array}$} \\
\hline & $\begin{array}{c}\mathrm{R} \\
\text { Square } \\
\text { Chang } \\
\mathrm{e}\end{array}$ & $\begin{array}{c}\text { F } \\
\text { Chang } \\
e\end{array}$ & df1 & $\mathrm{df} 2$ & $\begin{array}{c}\text { Sig. F } \\
\text { Chang } \\
\text { e }\end{array}$ & $\begin{array}{c}\mathrm{R} \\
\text { Square } \\
\text { Change } \\
\end{array}$ & $\begin{array}{c}\text { F } \\
\text { Chang } \\
\text { e }\end{array}$ & $\mathrm{df1}$ & $\mathrm{df} 2$ & \\
\hline 1 & ,820(a) & ,672 & ,668 & 17,610 & ,672 & 145,768 & 1 & 71 & ,000 & 1,870 \\
\hline
\end{tabular}

a Predictors: (Constant), Sosio_emosional

b Dependent Variable: Efektivitas_Kinerja

\subsection{Analisis Koefisien Determinasi}

Analisis regresi digunakan dalam peramalan variabel dependen berdasarkan variabel-variabel independennya.

\subsubsection{Koefisien Determinasi secara Parsial}

Pengaruh koefisien determinasi parsial diketahui dengan membaca output SPSS dan mengkalikan nilai Standardized Coefficients Beta (pada tabel coeficient) dengan nilai korelasi parsial. Kemampuan perencanaan koefisien determinasinya 11,1 persen, kemampuan pengorganisasian memiliki koefisien determinasi sebesar 27,5 persen, kemampuan pemimpinan memiliki koefisien determinasi 41,1 persen, kemampuan sosio-emosional memiliki koefisien determinasi sebesar 11,2 persen, dan kemampuan pengawasan memiliki koefisien determinasi sebesar 12,6 persen.

Tabel 4. Koefisien determinasi parsial

Coefficients(a)

\begin{tabular}{|l|c|c|c|c|}
\hline $\begin{array}{l}\text { Mode } \\
\mathrm{I}\end{array}$ & $\begin{array}{c}\text { Unstandardized } \\
\text { Coefficients }\end{array}$ & $\begin{array}{c}\text { Standardiz } \\
\text { ed } \\
\text { Coefficients }\end{array}$ & $\mathrm{t}$ & Correlations \\
\hline
\end{tabular}




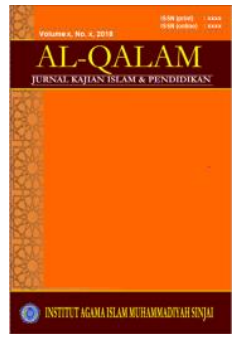

AL-QALAM

Jurnal Kajian Islam \& Pendidikan

Volume 9, No. 1, 2017

ISSN (print) : 1858-4152

ISSN (online) : :xxx-xxxx

Homepage : http://journal.iaimsinjai.ac.id/index.php/al-qalam

\begin{tabular}{|rl|r|r|r|r|r|r|r|}
\cline { 2 - 8 } & \multicolumn{1}{|c|}{ B } & \multicolumn{1}{c|}{$\begin{array}{c}\text { Std. } \\
\text { Error }\end{array}$} & Beta & \multicolumn{1}{c|}{$\begin{array}{c}\text { Zero- } \\
\text { order }\end{array}$} & Part & \multicolumn{1}{|c|}{$\begin{array}{c}\text { Toleran } \\
\text { ce }\end{array}$} & VIF \\
\hline 1 & $\begin{array}{l}\text { (Constant) } \\
\text { Sosio_emo } \\
\text { sional }\end{array}$ & $\begin{array}{r}83,27 \\
2\end{array}$ & 13,196 & & 6,310 & & & \\
& 2,923 &, 242 &, 820 & 12,073 &, 820 &, 820 &, 820 \\
\hline
\end{tabular}

a Dependent Variable: Efektivitas_Kinerja

\subsubsection{Koefisien Determinasi secara simultan}

Hasil estimasi ditunjukan pada nilai Rsquare (Tabel 4.22) dengan nilai Rsquere sebesar 0,930. Nilai tersebut menunjukan pengaruh kemampuan perencanaan, pengorganisasian, pemimpinan, kecerdasan emosional, pengawasan kepala sekolah dengan memberikan pengaruh terhadap peningkatan Efektivitas kinerja organisasi secara simultan (keseluruhan) adalah sebesar 93 persen

Tabel 5. Model Summary kemampuan perencanaan, pengorganisasian, pemimpinan, kecerdasan emosional, pengawasan kepala sekolah terhadap Efektivitas kinerja organisasi

\begin{tabular}{|l|r|r|r|r|r|}
\hline Model & $\mathrm{R}$ & R Square & $\begin{array}{c}\text { Adjusted R } \\
\text { Square }\end{array}$ & $\begin{array}{c}\text { Std. Error of } \\
\text { the Estimate }\end{array}$ & Durbin-Watson \\
\hline 1 &, $967(\mathrm{a})$ &, 935 &, 930 & 8,03457 & 1,544 \\
\hline
\end{tabular}

\subsubsection{Analisis Jalur, Pengaruh langsung dan Tidak langsung}

Tabel 6. Hasil analisis koefisien korelasi,Sig, thit, $F_{\text {hit, }}, R, R 2$, R Adjustment

\begin{tabular}{|l|c|c|c|c|c|c|c|c|c|c|c|}
\hline Variabel & Korelasi & $\mathrm{R}$ & $\begin{array}{c}\text { Koefisi } \\
\text { en Beta }\end{array}$ & $\mathrm{R} 2$ & $\mathrm{Thit}_{\mathrm{Df}} \mathrm{73}$ & tabel & $\begin{array}{c}\mathrm{P} \\
\text { Value } \\
\text { Sig }\end{array}$ & $\mathrm{F}_{\text {hit }}$ & $\mathrm{F}_{\text {tabel }}$ & $\begin{array}{c}\mathrm{R} 2 \\
\text { Adjust }\end{array}$ & Kesimpulan \\
\hline $\mathrm{X} 1-\mathrm{Y}$ & 0,950 & - & 0,442 & - & 3,889 & 1,993 &, 000 & - & - & - & Signifikan \\
\hline $\mathrm{X} 2-\mathrm{Y}$ & 0,814 & - & 0,119 & - & 2,105 & 1,993 &, 039 & - & - & - & Signifikan \\
\hline $\mathrm{X} 3-\mathrm{Y}$ & 0,777 & - & 0,132 & - & 2,648 & 1,993 &, 010 & - & - & - & Signifikan \\
\hline $\begin{array}{l}\mathrm{X} 1-\mathrm{X} 2- \\
\mathrm{X} 3-\mathrm{Y}\end{array}$ & & 0,967 & 21,149 & 0,935 & 2,250 & &, 028 & 191,628 & 2,340 & 0,930 & Signifikan \\
\hline
\end{tabular}

Hasil pengolahan di atas menunjukan analisis nilai korelasi secara parsial maupun simultan sangat kuat serta menunjukan pengaruh determinasi secara parsial dan simultan secara kuat yang dapat digambarkan pada gambar 3 sebagai berikut:

Gambar 3. Model Struktural korelasi Kemampuan sosio-emosional terhadap Efektifitas kinerja

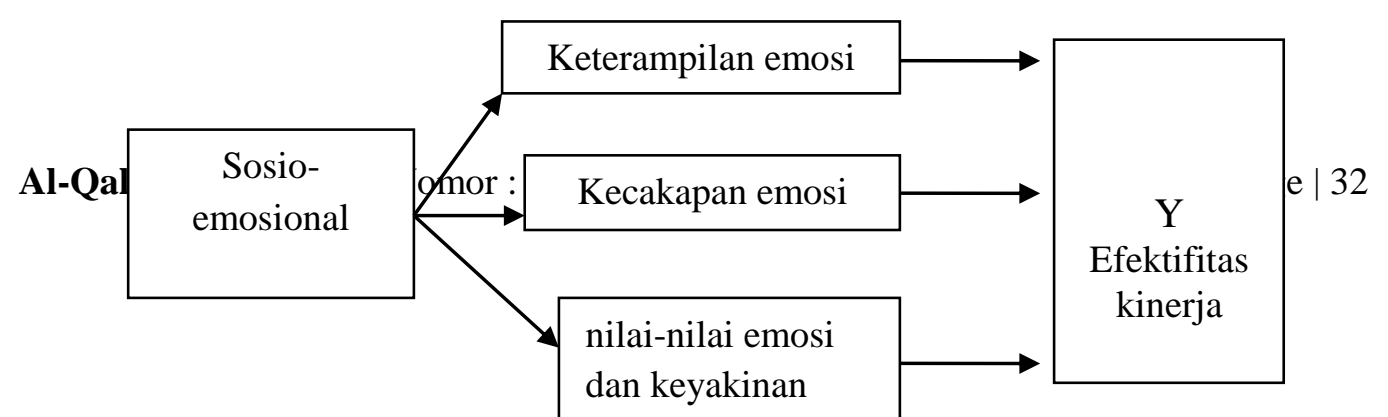




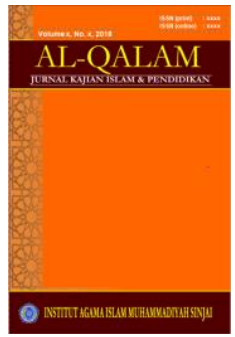

\subsection{Analisis Pengujian Hipotesis.}

Setelah dihitung ulang besarnya kontribusi/ pengaruh variabel independen terhadap variabel dependen, selanjutnya dilakukan uji signifikasi untuk mendapatkan kesimpulan yang lebih eksak dari hasil penelitian. Pengujian hipotesis dimulai dari uji sub struktur pertama, dan dilanjutkan dengan uji sub struktur kedua (model lengkap).

Tabel 7. Hasil analisis koefisien korelasi,Sig, $\mathrm{t}_{\text {hit }}, \mathrm{F}_{\text {hit }}, \mathrm{R}, \mathrm{R} 2$, $\mathrm{R}$ Adjustment

\begin{tabular}{|l|c|c|c|c|c|c|c|c|c|c|c|}
\hline Variabel & $\begin{array}{c}\text { Korela } \\
\text { si }\end{array}$ & $R$ & $\begin{array}{c}\text { Koefi } \\
\text { sien } \\
\text { Beta }\end{array}$ & $\mathrm{R} 2$ & $\begin{array}{c}\mathrm{T}_{\text {hit }} \\
\mathrm{Df}=73\end{array}$ & $\mathrm{t}_{\text {tabel }}$ & $\begin{array}{c}\mathrm{P} \\
\text { Value } \\
/ \text { Sig }\end{array}$ & $\mathrm{F}_{\text {hit }}$ & $\mathrm{F}_{\text {tabel }}$ & $\begin{array}{c}\mathrm{R} 2 \\
\text { Adjust }\end{array}$ & Kesimpulan \\
\hline $\mathrm{X} 1-\mathrm{Y}$ & 0,950 & - & 0,442 & - & 3,889 & 1,993 &, 000 & - & - & - & Signifikan \\
\hline $\mathrm{X} 2-\mathrm{Y}$ & 0,814 & - & 0,119 & - & 2,105 & 1,993 &, 039 & - & - & - & Signifikan \\
\hline $\mathrm{X} 3-\mathrm{Y}$ & 0,777 & - & 0,132 & - & 2,648 & 1,993 &, 010 & - & - & - & Signifikan \\
\hline $\begin{array}{l}\mathrm{X} 1-\mathrm{X} 2 \\
-\mathrm{X} 3-\mathrm{Y}\end{array}$ & & 0,967 & & 0,935 & & &, 028 & 191,628 & 2,340 & 0,930 & Signifikan \\
\hline
\end{tabular}

Sumber: Olah data Statistik, 2015

\subsubsection{Uji Hipotesis secara Parsial}

Dalam uji Hipotesis secara parsial dan simultan dapat ditunjukan dengan thit dan Ftabel dalam SPSS 15:0 seperti yang terlihat pada tabel 4.28 sebagai berikut

1. Signifikansi Keterampilan emosi dengan efektivitas kinerja kepala sekolah

Hipotesis yang akan diuji adalah pengaruh Keterampilan emosi yang meliputi: kesadaran emosi diri, kesadaran emosi terhadap orang lain, peristiwa dalam hidup dengan efektivitas kinerja kepala sekolah.

Untuk membuktikan hipotesis tersebut dilakukan pengujian terhadap hipotesis statistik yang diuji menggunakan uji $\mathrm{t}$ dan rangkuman hasil pengujiannya yaitu nilai $t_{\text {hitung }}$ sebesar 2,105 dengan nilai signifikan ( $p$-value) lebih besar dari 0,05 . Karena thitung $(2,105)$ lebih besar dibanding $t_{\text {tabel }}$ 


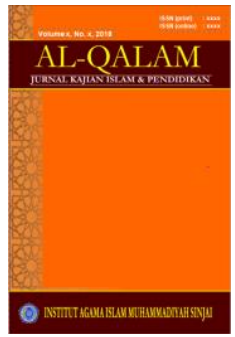

AL-QALAM

Jurnal Kajian Islam \& Pendidikan

Volume 9, No. 1, 2017

ISSN (print) : 1858-4152

ISSN (online) : :xxx-xxxx

Homepage : http://journal.iaimsinjai.ac.id/index.php/al-qalam

(1,993) maka pada tingkat kekeliruan 5\% ada alasan yang kuat untuk menolak $\left(\mathrm{H}_{0}\right)$ dan menerima hipotesis penelitian $\left(\mathrm{H}_{\mathrm{a}}\right)$, sehingga dengan tingkat kepercayaan 95\% dapat disimpulkan bahwa kemampuan sosioemosional berpengaruh signifikan terhadap efektivitas kinerja kepala sekolah. kesimpulannya bahwa nilai $\mathrm{t}_{\text {hitung }}$ jatuh di daerah penolakan $\mathrm{H}_{0}$ yang berarti adanya pengaruh positif dan signifikan secara parsial dari kemampuan sosioemosional terhadap efektivitas kinerja kepala sekolah sebesar 0,119 atau $11,9 \%$

2. Signifikansi Kecakapan emosi dengan efektivitas kinerja kepala sekolah

Hipotesis yang akan diuji adalah pengaruh Kecakapan emosi yang meliputi: Intensionalitas, kreatifitas, ketangguhan, hubungan antarpribadi, dan kepuasan konstruktif

3. Signifikansi nilai-nilai emosi dengan efektivitas kinerja kepala sekolah

Hipotesis yang akan diuji adalah pengaruh Nilai-nilai emosi dan keyakinan yang meliputi: belas kasihan, sudut pandang, Intuisi, radius kepercayaan, daya pribadi, serta integritas.

\subsubsection{Uji Hipotesis secara Simultan}

Pengujian secara keseluruhan (simultan) dilakukan untuk membuktikan apakah ada pengaruh dari paling sedikit satu variabel bebas terhadap variabel tak bebasnya. Pengujian ini dilakukan menggunakan distribusi $F$ dengan membandingkan antara nilai $F_{\text {hitung }}$ dengan nilai $F_{\text {tabel. }}$ Jika nilai $F_{\text {hitung }}>F_{\text {kritis, }}$, maka $\mathrm{H}_{0}$ yang menyatakan bahwa variasi perubahan nilai variabel bebas (kemampuan sosio-emosional) tidak dapat menjelaskan perubahan nilai variabel terikat (efektivitas kinerja) ditolak dan sebaliknya. Berdasarkan perhitungan SPSS

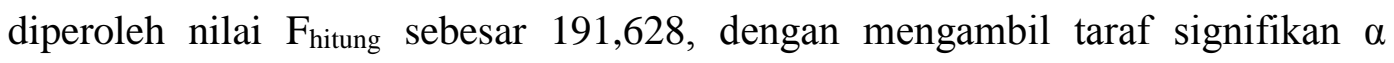
sebesar 5\%, maka dari tabel distribusi $\mathrm{F}$ didapat nilai $\mathrm{F}_{\text {tabel }}$ untuk $\mathrm{n}=73$; $\mathrm{k}=5$; df $=\mathrm{n}-\mathrm{k}-1=73-5-1=67$; diperoleh nilai sebesar 2,340. Dikarenakan $F_{\text {hitung }}>F_{\text {tabel }}$ yaitu 191,628 > 2,340, Ho ditolak, artinya secara simultan terdapat pengaruh signifikan kemampuan sosio-emosional terhadap efektivitasas kinerjai. 


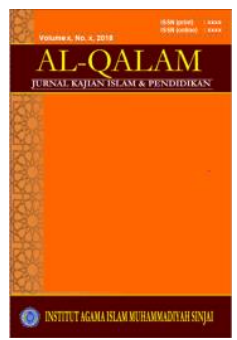

AL-QALAM

Jurnal Kajian Islam \& Pendidikan

Volume 9, No. 1, 2017

ISSN (print) : 1858-4152

ISSN (online) : xxxx-xxxx

Homepage : http://journal.iaimsinjai.ac.id/index.php/al-qalam

Kesimpulan dari nilai koefisien determinasi yang disesuaikan (adjusted R2 ) yakni sebesar 0.930 atau $93 \%$. sekaligus menjelaskan adanya pengaruh variabel-variabel di luar model yaitu 1 - adjusted $\mathrm{R} 2=0.070$ atau $7 \%$.

Berdasarkan hasil analisis data dapat disimpulkan bahwa hipotesis yang diajukan dalam penelitian ini diterima. Hal ini menunjukkan bahwa terdapat pengaruh yang signifikan antara kemampuan sosio-emosional dengan efektivitas kinerja secara bersama-sama. Hasil ini mengandung arti bahwa model teoritis yang diajukan sejalan dengan kondisi empirisnya. Hal ini sesuai dengan pendapat George R. Terry ${ }^{3}$ (Silalahi, 2002), dalam bukunya yang berjudul Principles of Management, Terry mengklasifikasikan fungsi-fungsi manajemen yaitu 1) Planning (perencanaan), 2) Organizing (pengorganisasian), 3) Actuating (penggerakan), dan 4) Controlling (pengawasan). Dilanjutkan oleh James A. F. Stoner. (1996:34) dalam bukunya "Administration" mengklasifikasikan fungsifungsi manajemen yaitu a) Planning (Perencanaan), b) Organizing (Pengorganisasian), c) Leading (Pemimpinan), d) Controlling (Pengendalian) menyatakan bahwa efektifitas kinerja organisasi tersebut diperoleh melalui kemampuan faktor-faktor tersebut dan ditambah pendapat Goleman dan Aiman Sawaf ahli Psikologi, menyatakan kesuksesan seseorang dalam mencapai efektifitas dan efisisiensi organisasi sangat dipengaruhi oleh kemampuan mengelola emosinya dalam berhubungan dengan orang lain, dalam hal ini penulis menyebutnya dengan kemampuan sosio-emosional. Dengan demikian sangat penting untuk mempertahankan dan meningkatkan efektifitas kinerja organisasi lewat kemampuan manajerial yang dimiliki oleh kepala sekolah dalam lingkungan manajemen berbasis sekolah yang dinamis dan kompetitif.

Dalam penelitian ini, Secara umum terdapat dua aspek yang menjadi kata kunci yaitu kontribusi faktor-faktor kemampuan manajerial terhadap kinerja kepala sekolah dan dampaknya pada keefektivitan sekolah di Kabupaten Sinjai.

${ }^{3}$ G.R. Terry.. The principle of Management. Illionis, (USA, Richard D Irwin inc. 1968) 


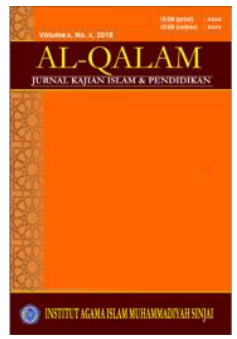

AL-QALAM

Jurnal Kajian Islam \& Pendidikan

Volume 9, No. 1, 2017

ISSN (print) : 1858-4152

ISSN (online) : xxxx-xxxx

Homepage : http://journal.iaimsinjai.ac.id/index.php/al-qalam

Dalam operasional variabel terdapat dua kelompok variabel yang dikaji yaitu variabel bebas dan variabel terikat.

Kemampuan manajerial Kepala Sekolah adalah kapasitas yang dimiliki oleh seorang Kepala Sekolah dalam mengelola organisasi dan sumberdaya yang ada guna pencapaian tujuan organisasi yang mencakup: Kecerdasan emosional/ Sosio-emosional Kepala Sekolah yang diukur dalam penelitian ini memfokuskan pada tiga dimensi yaitu (1) Keterampilan emosi yang meliputi: kesadaran emosi diri, kesadaran emosi terhadap orang lain, peristiwa dalam hidup.; (2) Kecakapan emosi yang meliputi: Intensionalitas, kreatifitas, ketangguhan, hubungan antarpribadi, dan kepuasan konstruktif; dan (3) Nilai-nilai emosi dan keyakinan, yang meliputi: belas kasihan, sudut pandang, Intuisi, radius kepercayaan, daya pribadi, serta integritas;

Keefektifan kinerja dalam MBS adalah seperangkat skor yang dicapai dari sejumlah dimensi kinerja sekolah yang efektif yang meliputi: a) produktivitas yang indikatornya meliputi: (1) Jumlah hasil kerja organisasi/sekolah, (2) Mutu/kualitas hasil kerja organisasi/sekolah, (3) Daya saing produktivitas organisasi/sekolah, dan (4) Kesesuaian produktivitas dengan tujuan organisasi, b) kualitas layanan, yang indikatornya meliputi: (1) Kualitas layanan organisasi/sekolah, (2) Kesabaran menghadapi masalah yang timbul, (3) Kemampuan bertindak cepat atas permintaan, (4) Kesopanan dan keramahan pegawai dan c) responsivitas, indikatornya meliputi: (1) Kemampuan mengaitkan program kegiatan dengan kebutuhan organisasi, (2) Spontanitas daya tanggap pegawai, (3) Tersedianya wadah pelayanan masyarakat, (4) Keterbukaan pegawai dalam organisasi.

\section{Kontribusi indikator sosio- emosional kepala sekolah sendiri-sendiri terhadap efektifitas kinerja sekolah}

Kecerdasan emosional/ Sosio-emosional Kepala Sekolah yang diukur dalam penelitian ini memfokuskan pada tiga dimensi yaitu (1) Keterampilan emosi yang meliputi: kesadaran emosi diri, kesadaran emosi terhadap orang lain, peristiwa 


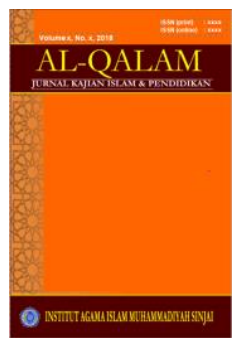

dalam hidup.; (2) Kecakapan emosi yang meliputi: Intensionalitas, kreatifitas, ketangguhan, hubungan antarpribadi, dan kepuasan konstruktif; dan (3) Nilai-nilai emosi dan keyakinan, yang meliputi: belas kasihan, sudut pandang, Intuisi, radius kepercayaan, daya pribadi, serta integritas. Kecakapan seseorang Kepala Sekolah menggambarkan kemampuan untuk memandang situasi sekolah dan pembelajaran dari sudut pandang guru dan pegawai dengan tujuan mendorong mereka untuk sukses dalam bekerja. Dalam kondisi semacam itu Kepala Sekolah harus berupaya mengamati dan membuka telinga untuk mendengarkan apa yang penting bagi keberhasilan para bawahannya.

Berdasarkan hasil analisis dapat disimpulkan bahwa terdapat kontribusi yang positif dan signifikan antara kemampuan Kecerdasan emosional/ Sosioemosional Kepala Sekolah dengan kinerja organisasi di Kabupaten Sinjai dengan kontribusi sebesar 0.119 satuan dengan asumsi faktor lain konstan atau naik 11,9\%. Dengan kata lain dapat dinyatakan bahwa makin baik tingkat kemampuan Kecerdasan emosional/ Sosio-emosional Kepala Sekolah, semakin tinggi pula tingkat kinerja organisasi Sekolah di Kabupaten Sinjai, sedangkan sisanya lagi $89,10 \%$ merupakan kontribusi faktor lain. Determinasi kemampuan Kecerdasan emosional/ Sosio-emosional Kepala Sekolah ada sebesar 11,9\% mengidentifikasikan bahwa kemampuan Kecerdasan emosional/ Sosio-emosional Kepala Sekolah dapat dipakai sebagai prediktor kinerja organisasi sekolah di Kabupaten Sinjai.

Kepala Sekolah di Kabupaten Sinjai lebih sering menampakkan kekuasaan dan pemaksaan kepada guru dan pegawai, atau seorang guru bersikap otoriter kepada para siswa, maka kini orientasi itu harus diubah. Tugas pokok guru dan pegawai sekolah adalah melayani siswa dan tugas kepala sekolah adalah melayani guru dan pegawai.

Salah satu kunci agar dapat melayani dengan baik, Kepala Sekolah harus memahami pelanggannya. Kepala Sekolah hendaknya mampu mengidentifikasi kebutuhan para pelanggan yang sesungguhnya, yang tersirat dan sering tidak 


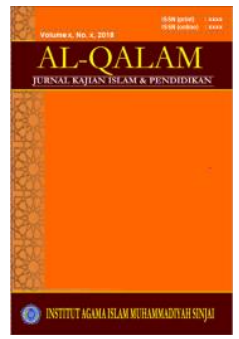

AL-QALAM

Jurnal Kajian Islam \& Pendidikan

Volume 9, No. 1, 2017

ISSN (print) : 1858-4152

ISSN (online) : xxxx-xxxx

Homepage : http://journal.iaimsinjai.ac.id/index.php/al-qalam

disadari mereka dan kemudian mencocokkan kebutuhan mereka dengan pelayanan yang selama ini diberikan. Dalam orientasi pelayanan semacam itu, hubungan menjadi sangat penting untuk dibangun yang bersifat jangka panjang yang kadang-kadang menuntut pengorbanan demi mempertahankan dan melestarikan hubungan tersebut.

Agar unggul dalam pelayanan, memantau kepuasan para pelanggannya, mengemukakan keluhannya. Aktivitas ini, seorang Kepala Sekolah perlu bukan sekedar menunggu sampai mereka dapat dilakukan secara bersamaan ketika kepala sekolah melakukan kegiatan evaluasi dan monitoring di sekolah.

\section{Kontribusi Indikator Sosio-emosional kepala sekolah secara bersama sama terhadap efektifitas kinerja sekolah}

Berdasarkan hasil analisis dapat disimpulkan bahwa terdapat kontribusi yang positif dan signifikan antara kemampuan kecerdasan emosional kepala sekolah secara bersama sama terhadap efektifitas kinerja sekolah di Kabupaten Sinjai dengan kontribusi sebesar 93\% Sedangkan sisanya lagi 7\% merupakan kontribusi faktor lain yang tidak diteliti. Dengan demikian dapat disimpulkan bahwa hipotesis nol $\left(\mathrm{H}_{0}\right)$ yang menyatakan "tidak terdapat kontribusi yang positif dan signifikan antara kemampuan perencanaan, pengorganisasian, kepemimpinan, kecerdasan emosional dan pengawasan kepala sekolah secara bersama sama terhadap efektifitas kinerja sekolah di Kabupaten Sinjai ditolak. Sedangkan hipotesis alternatif $\left(\mathrm{H}_{\mathrm{a}}\right)$ yang menyatakan "terdapat kontribusi yang positif dan signifikan antara kemampuan kecerdasan emosional kepala sekolah secara bersama sama terhadap efektifitas kinerja sekolah di Kabupaten Sinjai" dapat diterima. Hal menarik dari penelitian yang diperoleh adalah Kemampuan manajerial yang paling dominan adalah kemampuan pemimpinan.

\section{KESIMPULAN DAN SARAN}




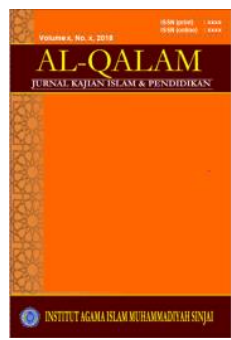

AL-QALAM

Jurnal Kajian Islam \& Pendidilkan

Volume 9, No. 1, 2017

ISSN (print) : 1858-4152

ISSN (online) : xxxx-xxxx

Homepage : http://journal.iaimsinjai.ac.id/index.php/al-qalam

\section{A. Kesimpulan}

Berdasarkan hasil penelitian dan pembahasan yang telah dikemukakan, diperoleh kesimpulan sebagai berikut:

Deskripsi kemampuan kecerdasan emosional (sosio-emosional) kepala sekolah dengan efektifitas kinerjanya di Kabupaten Sinjai tergolong baik, dari tiga subvariabel yaitu Keterampilan emosi yang meliputi: kesadaran emosi diri, kesadaran emosi terhadap orang lain, peristiwa dalam hidup; Kecakapan emosi yang meliputi: Intensionalitas, kreatifitas, ketangguhan, hubungan antarpribadi, dan kepuasan konstruktif; dan Nilai-nilai emosi dan keyakinan, yang meliputi: belas kasihan, sudut pandang, Intuisi, radius kepercayaan, daya pribadi, serta integritas. Hasil pengujian variabel sosio-emosional berdasarkan aspeknya diperoleh nilai terendah yaitu nilai-nilai emosi dan keyakinan, serta kecakapan emosi. Nilai-nilai emosi yang paling lemah adalah belas kasihan dan radius kepercayaan, penyebabnya adalah budaya belas kasihan, menolong rekan dan bawahan pada hasil, bukan proses yang menyebabkan tidak produktif bahkan cenderung apatis. Demikian juga dengan kecakapan emosi dimensi yang lemah adalah kreatifitas, kepala sekolah menganggap aturan sebagai patokan bekerja, kreatifitas cenderung berbenturan dengan aturan, karena itu kreatifitas sering diabaikan sebagai faktor yang mesti didukung sepenuhnya. Sedang keterampilan emosi cenderung sangat baik, ini berkaitan dengan peristiwa dalam hidup dari kepala sekolah cenderung melekat kuat yang dibawa sampai dalam kegiatan manajerial.

Kemampuan sosio-emosional kepala sekolah berpengaruh secara signifikan terhadap efektivitas kinerjanya. Hal ini menunjukkan dengan semakin baiknya keterampilan sosio-emosional kepsek semakin baik pula kinerja sekolah dan akan memberikan dampak terhadap semakin meningkatnya efektivitas sekolah.

\section{B. Saran}




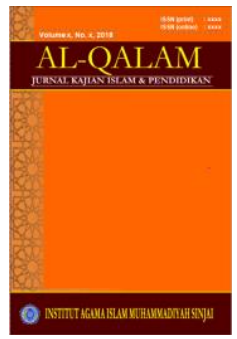

AL-QALAM

Jurnal Kajian Islam \& Pendidikan

Volume 9, No. 1, 2017

ISSN (print) : 1858-4152

ISSN (online) : :xxx-xxxx

Homepage : http://journal.iaimsinjai.ac.id/index.php/al-qalam

Berdasarkan hasil interpretasi data, pembahasan dan kesimpulan diatas, maka penulis merekomendasikan beberapa hal dalam rangka terwujudnya efektivitas kinerja organisasi yang berkaitan dengan kemampuan manajerial kepala sekolah di Kabupaten Sinjai yaitu:

1. Dengan otonomi daerah, pemerintah daerah dan pemerintah pusat membuat kebijakan yang mengarah pada peningkatan kinerja kepala sekolah dan efektifitas kinerja organisasi sekolah.

2. Penegasan kembali tugas pokok dan fungsi (tupoksi) terutama kemampuan manajerial kepala sekolah dengan pendidikan dan pelatihan yang terencana.

3. Menyusun persyaratan untuk rekrutmen kepala sekolah yang didasarkan pada profesionalisme kemampuan manajerial dengan mempertimbangkan tingkat pendidikan, masa kerja/golongan, pengalaman manajerial, sosio-emosional, dedikasi dan loyalitas terhadap sekolah terutama implementasi fungsi-fungsi manajerial dalam fit and proper test.

4. Pengangkatan kepala sekolah harus dibekali pendidikan dan latihan kepala sekolah terutama kemampuan manajerial dan sosio-emosional.

5. Rotasi kepala sekolah berdasarkan pada peningkatan kinerja kepala sekolah dan efektifitas kinerja sekolahnya, serta berlaku prestasi objektif (penghargaan atau sanksi).

6. Memaksimalkan peran pengawas sekolah melalui pembuatan program pengawasan dan penilaian terhadap kepala sekolah yang objektif, sehingga bagi kepala sekolah yang berprestasi baik personal maupun lembaganya diberikan tunjangan prestasi yang memadai.

7. Berpegang pada prinsip-prinsip manajer yang sukses, yaitu manajer yang berorientasi nilai (yaitu pemimpin yang mampu melibatkan moral dan kecerdasan emosional menjadi sifat-sifat internal) yaitu ketulusan, kejujuran, terpercaya, setia dan harga diri. Prinsip selanjutnya adalah menyiapkan diri, mendisiplinkan diri, memotivasi diri, berilmu pengetahuan, berorientasi daya 


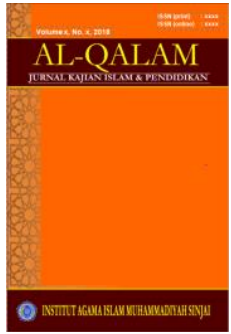

AL-QALAM

Jurnal Kajian Islam \& Pendidikan

Volume 9, No. 1, 2017

ISSN (print) : 1858-4152

ISSN (online) : :xxx-xxxx

Homepage : http://journal.iaimsinjai.ac.id/index.php/al-qalam

guna seperti komunikator, menjadi motivator, menjadi pemecah masalah, menjadi kelompok pembangun, bertanggungjawab dan kreatif.

\section{DAFTAR PUSTAKA}

Creswell, J.W., 2009. Research Design Qualitatif, Quantitatif, and Mixed Methods Approaches. California. Sage Publications.

Depdiknas. 2007. Standar Kompetensi Kepala Sekolah. Penerbit Direktorat Penjaminan Mutu Pendidikan Menengah, Departemen Pendidikan Nasional.

Mamduh, M. 1997. Manajemen. Unit Penerbit Dan Percetakan AMP YKPN.

Peraturan Menteri Pendidikan Nasional Nomor 28 tahun 2010 tentang penugasan guru sebagai kepala sekolah/Madrasah

Riggio,R.E.,Riggio,H.R., Salinas, C., \& Cole, E.J. 2003. The role of social and emotional communication skills in leader emergence and effectiveness. Group Dynamics: Theory, Research, and Practice, 7, 83-103.

Robbins, S. P. 1994. Management. Fourth Edition ed, New Jersey: Prentice Hall.

Sangkala. 2012. Dimensi-Dimensi Manajemen Publik. penerbit Ombak, Yogyakarta.

Stoner, James A, et all. 1995. Management. Jakarta, second edition, diterjemahkan Erlangga.

Terry, G.R. 1968. The principle of Management. Illionis, USA, Richard D Irwin inc. 